\title{
Thermomicrobium fosteri sp. nov., a Hydrocarbon-Utilizing Obligate Thermophile ${ }^{1}$
}

\author{
WALTER E. PHILLIPS, JR., AND JEROME J. PERRY \\ Department of Microbiology, North Carolina State University, Raleigh, North Carolina 27607
}

\begin{abstract}
A hydrocarbon-utilizing, obligately thermophilic bacterium was isolated from a littoral area of North Carolina, and it is herein described and named as a new species. The microorganism, designated strain PTA-1, is a gram-negative, nonsporeforming, nonmotile, pleomorphic rod that can utilize various long-chain $n$ alkanes, 1-alkenes, primary alcohols, or ketones as substrates for growth. It will not grow on nutrient broth or Trypticase soy broth. The organism is an obligate aerobe which grows most rapidly at $60 \mathrm{C}$ with a generation time of 4.0 to $4.5 \mathrm{~h}$ at an optimum $\mathrm{pH}$ of 7.2 to 7.5 in minimal salts medium with $0.1 \% n$-heptadecane as substrate. The temperature range for growth is 42 to $70 \mathrm{C}$. A deoxyribonucleic acid base composition of $68.8 \mathrm{~mol} \%$ guanine plus cytosine for this organism was determined by thermal denaturation of isolated deoxyribonucleic acid. The cells contain a pink carotenoid pigment(s) that is most evident after growth at minimal temperatures with acetate as the substrate. It is proposed that this organism be placed in the genus Thermomicrobium as a new species, to which we give the name Thermomicrobium fosteri. The type strain of $T$. fosteri, PTA1, has been deposited in the American Type Culture Collection under the number 29033.
\end{abstract}

Thermophilic bacteria have been studied since the first isolation of this kind of microorganism, from the Seine River by Miquel (15) in 1879. In the early studies, the great majority of bacteria isolated at high temperatures were gram-positive, aerobic sporeformers of the genus Bacillus (for a review, see reference 1). Recently (1969), Brock and Freeze (3) reported on the isolation of an extremely thermophilic, gram-negative, aerobic, nonsporeforming, rodshaped bacterium, which they named Thermus aquaticus. Other species of Thermus have since been isolated and characterized $(16,20)$. In 1973, Jackson et al. (6) isolated an extremely thermophilic, gram-negative bacterium from an alkaline hot spring in Yellowstone National Park and considered it sufficiently different from the members of the currently recognized genera to propose a new genus, Thermomicrobium, for this microorganism. The type species of Thermomicrobium is $T$. roseum, of which the type strain is American Type Culture Collection (ATCC) strain 27502.

Kvasnikov et al. (10) described the physiological properties of a gram-positive sporeformer, Bacillus circulans subsp. thermophilus, which utilized $n$-alkanes as sole sources of carbon and energy. Other strains belonging to the genus Bacillus and capable of growth on $n$-alkanes

\footnotetext{
${ }^{1}$ Paper no. 4621 of the Journal Series of the North Carolina Agricultural Experiment Station, Raleigh, N.C. 27607.
}

and paraffin at optimum temperatures of 55 to $60 \mathrm{C}$ have been described $(14,17,19)$. However, studies on thermophilic, gram-negative, hydrocarbon-utilizing bacteria are limited in number and involve mostly thermotolerant and thermoresistant strains of Pseudomonas (18). The isolation and nutritional characterization of extremely thermophilic, gram-negative bacteria $(3,6,16,20)$ have been described with substrates such as tryptone, yeast extract, sugars, and organic acids, but none of these isolates utilized hydrocarbons or related substrates. This investigation concerns the isolation and classification of an obligately thermophilic, gram-negative, hydrocarbon-utilizing bacterium.

\section{MATERIALS AND METHODS}

Bacterial strain. The bacterium utilized in this study was isolated from a mud sample obtained from a littoral area near Beaufort, N.C., and was designated strain PTA-1. This strain can be maintained in a freeze-dried state at $-10 \mathrm{C}$.

Isolation and media. Initial isolation of the thermophilic bacterium was accomplished by enrichment culture at $50 \mathrm{C}$. A diluted mud sample was placed in the basal salts medium (L-salts) of Leadbetter and Foster (11), with $0.1 \%$ (vol/vol) $n$-hexadecane added as growth substrate. Since the organism does not grow readily on solid substrates, purification of the isolate was accomplished by serial dilution to extinction in L-salts containing $0.1 \%$ (vol/vol) $n$-hexadecane. Substrate specificity tests were per- 
formed in 125-ml Erlenmeyer flasks containing 30 $\mathrm{ml}$ of L-salts supplemented with $0.2 \%$ (vol/vol) liquid substrate or $0.2 \%$ (wt/vol) solid substrate. The utilization of gaseous hydrocarbons was determined as described previously (21). Strain PTA-1 was cultivated after isolation and purification by adding substrate to melted agar in a blender and mixing to give a stable emulsion. A $50-\mathrm{ml}$ amount of the blended agar was added to a glass petri dish (20 by $100 \mathrm{~mm}$ ). The plates were inoculated and incubated in a desiccator, the bottom of which was covered with water. Visible colonies appeared after 14 days.

Substrates. The hydrocarbon substrates employed in this study had a minimum purity of $99 \%$. The liquid hydrocarbon substrates were sterilized by membrane filtration.

Growth conditions. Cells were grown in 2-liter Erlenmeyer flasks containing $500 \mathrm{ml}$ of L-salts medium ( $\mathrm{pH} 7.2$ ) supplemented with $0.2 \%$ (wt/vol) sodium acetate or $0.1 \%$ (vol/vol) hydrocarbon as substrate. The cultures were incubated at selected temperatures on a gyratory shaker at $180 \mathrm{rpm}$. The organism was preadapted to the appropriate substrate at the test temperature before use as inoculum. Growth was measured turbidometrically at 600 $\mathrm{nm}$ or by dry weight of cells.

Electron microscopy. The procedures used for electron microscopy, including fixation, dehydration, and embedding of microorganisms, were described previously $(8,9)$.

Dipicolinic acid. Dipicolinic acid assays were by the method of Janssen et al. (7), with Bacillus circulans as a control.

DNA base composition. Deoxyribonucleic acid (DNA) was isolated and purified by the method of Marmur (12). The moles percent guanine plus cytosine $(G+C)$ was determined by thermal denaturation (13) using a Beckman DUR spectrophotometer attached to a Gilford 2000 multiple-sample absorbance recorder.

Pigment(s). The pigments were extracted from PTA-1 cells by the method of Eimhjellen and Jensen (5). The absorption spectrum of the pigment(s) was determined with a Beckman Acta $V$ recording spectrophotometer, using a cuvette of $10-\mathrm{mm}$ path length.

\section{RESULTS}

Cellular morphology. The organism was a rod with singly occurring cells that had an average length of $1.5 \mu \mathrm{m}$. The cells were gram negative and nonmotile. No endospores were observed in the cells by phase-contrast microscopy, and all assays for dipicolinic acid after growth under various cultural conditions were negative. An electron micrograph (Fig. 1) of ultrathin sections of strain PTA-1 demonstrated that the cells were short rods. A multilayered cell wall characteristic of the gramnegative thermophile Thermomicrobium roseum (6) was observed. The cells contained an extensive network of intracellular membranes resembling mesosomes, and intracytoplasmic hydrocarbon inclusions, similar to those described in an acinetobacter (9), are evident in cells after growth on $n$-heptadecane.

Growth characteristics. No growth was obtained with nutrient broth (Difco) or tryptic soy broth (Difco) as the substrate. The ability of strain PTA-1 to utilize various substrates was determined (Table 1). The organism can utilize long-chain $n$-alkanes, 1 -alkenes, primary alcohols, and ketones, but not the shorter-chain compounds, as substrates for growth. Neither cycloparaffins nor aromatic hydrocarbons served as growth substrates. Strain PTA-1 grew with acetate $(\mathrm{Na})$ as the substrate but not with citrate $(\mathrm{Na})$ or succinate $(\mathrm{Na})$, and it utilized both ammonia and nitrate as sources of nitrogen.

The $\mathrm{pH}$ range for optimum growth of strain PTA-1 was 7.2 to 7.5. No growth was observed at temperatures above $70 \mathrm{C}$ or below $42 \mathrm{C}$. The effect of growth temperature on the generation time of strain PTA-1 is shown in Fig. 2. At temperatures of $50,55,60$, and $65 \mathrm{C}$, the generation times were approximately $15.0,9.0,4.5$, and $9.0 \mathrm{~h}$, respectively.

Pigment(s). A pink, water-insoluble pigment(s) was produced by the organism when grown with sodium acetate as the substrate. Although not quantitatively determined, it appeared that strain PTA-1 produced more pigment at $50 \mathrm{C}$ than at 60 or $65 \mathrm{C}$. The absorbance spectrum of the acetone-extractable pigment(s) is shown in Fig. 3. The maximum absorption occurred at $477 \mathrm{~nm}$, with secondary peaks appearing at $385,448,507$, and $550 \mathrm{~nm}$.

DNA base composition. The $\mathrm{G}+\mathrm{C}$ content of the DNA from strain PTA-1 was $68.8 \mathrm{~mol} \%$, and the ratio of the optical density at 260 and $280 \mathrm{~nm}$ of the purified DNA was 1.82 .

\section{DISCUSSION}

The salient characteristics of various gramnegative, nonsporulating, obligate thermophiles are presented in Table 2 . The $\mathrm{G}+\mathrm{C}$ values for all of these organisms fall within a range of 64.3 to $69.0 \mathrm{~mol} \%$. The maximum and optimum growth temperatures for strain PTA-1 are somewhat lower than those for T. aquaticus, T. thermophilus, and T. roseum, although the minimum temperature at which each will grow is virtually the same for all of these thermophilic organisms. The optimum $\mathrm{pH}$ for growth of strain PTA-1 is equivalent to that for the members of the genus Thermus and lower than that for $T$. roseum. The higher $\mathrm{pH}$ required by $T$. roseum may be a reflection of the niche from which it was isolated (alkaline thermal environment).

Strain PTA-1 differs in many respects from 

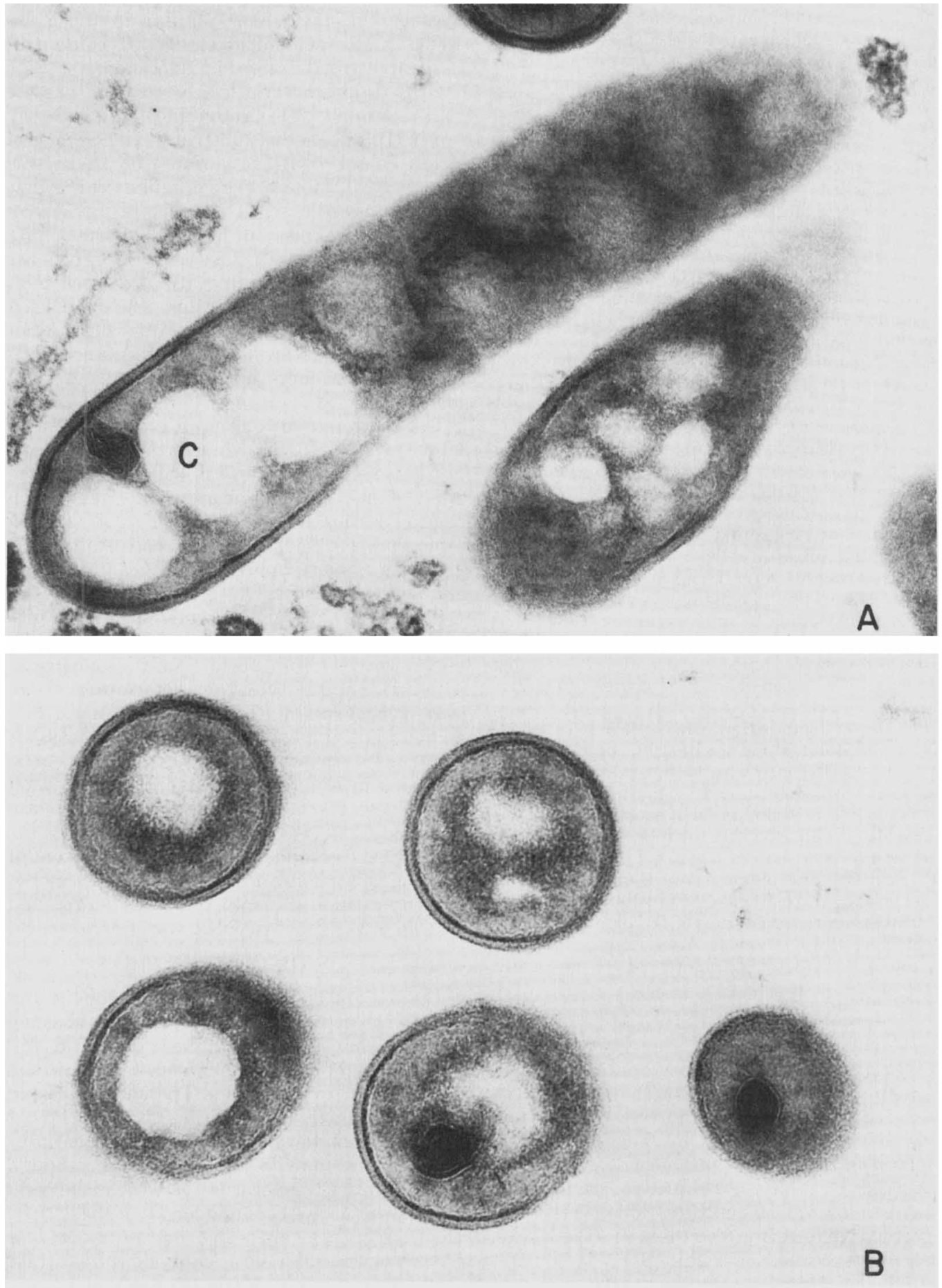

FIG. 1. Electron micrograph of a thin section of strain PTA-1. The total magnification in the longitudinal section $(A)$ was $\times 85,000$ and for $(B)$ it was $\times 88,000$. Note the hydrocarbon inclusions $(C)$. 
TABLE 1. Ability of strain PTA-1 to utilize various hydrocarbons and related compounds as growth substrates $^{a}$

\begin{tabular}{|c|c|}
\hline Substrates ${ }^{b}$ & $\begin{array}{l}\text { Growth re- } \\
\text { sponses }^{c}\end{array}$ \\
\hline \multicolumn{2}{|l|}{$n$-Alkanes } \\
\hline $\mathrm{C}_{1-9}$ & - \\
\hline $\mathrm{C}_{10-20}$ & + \\
\hline \multicolumn{2}{|l|}{ Methylalkanes } \\
\hline $\mathrm{C}_{19}$ & + \\
\hline \multicolumn{2}{|l|}{ 1-Alkenes } \\
\hline $\mathrm{C}_{7-13}$ & - \\
\hline $\mathrm{C}_{14-18}$ & + \\
\hline \multicolumn{2}{|l|}{ Alcohols } \\
\hline $\mathrm{C}_{4-11}$ & - \\
\hline $\mathrm{C}_{12-17}$ & + \\
\hline \multicolumn{2}{|l|}{ Ketones } \\
\hline $\mathrm{C}_{4-13}$ & - \\
\hline $\mathrm{C}_{14-17}$ & + \\
\hline Cycloparaffins and aromatics & - \\
\hline Alkynes & - \\
\hline Acetate & + \\
\hline Citrate & - \\
\hline Succinate & - \\
\hline D-Glucose & - \\
\hline
\end{tabular}

$a$ Test flasks contained L-salts with either 50:50 (vol/vol) gaseous substrate-air mixture or $0.2 \%$ ( $\mathrm{vol} /$ vol or wt/vol) substrate added. Incubation was on a rotary shaker at $60 \mathrm{C}$ for 2 weeks.

${ }^{b}$ Substrates tested: $n$-alkanes - from $\mathrm{C}_{1}$ to $\mathrm{C}_{20}$; methylalkanes-2-methyloctadecane, 3-methyloctadecane, 4-methyloctadecane; 1-alkenes-from $\mathrm{C}_{7}$ to $\mathrm{C}_{18}$; 1-alcohols-from $\mathrm{C}_{4}$ to $\mathrm{C}_{17}$; ketones-2-butanone, 2-pentanone, 2-heptanone, 2-undecanone, 2dodecanone, 2-tridecanone, 3-tetradecanone, 2-pentadecanone, 2-hexadecanone, 9-heptadecanone; cycloparaffins - from $\mathrm{C}_{5}$ to $\mathrm{C}_{8}$; aromatics-benzene, oxylene, $m$-xylene, $p$-xylene; alkynes - from $C_{15}$ to $\mathrm{C}_{18}$.

$"+$, Growth in excess of $0.1 \mathrm{mg}$ of dry weight per $\mathrm{ml}$; -, no growth. members of the genus Thermus, but it closely resembles Thermomicrobium roseum. The 4.0to 4.5-h generation time for strain PTA-1 is near that for $T$. roseum and is distinctly different from those (20 to $50 \mathrm{~min}$ ) of the known Thermus species. The cellular morphology of

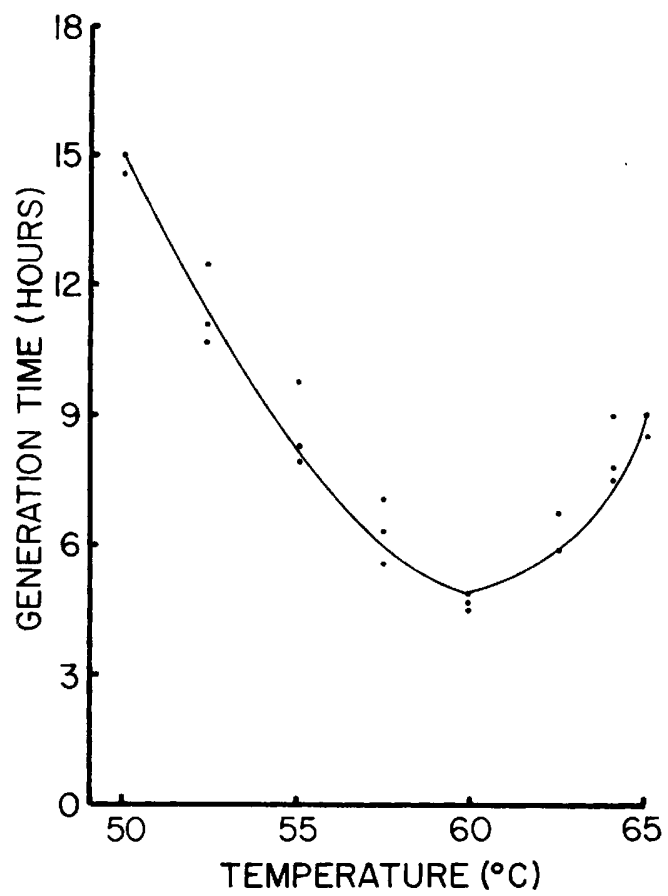

FIG. 2. Effect of growth temperature on the generation time of strain PTA-1. Cells were grown in $L$ salts basal medium ( $p H$ 7.2) with $0.1 \%$ (vol/vol) $n$ heptadecane as the substrate. Incubation was accomplished on a rotary shaker at $180 \mathrm{rpm}$.

TABLE 2. Salient characteristics of gram-negative, nonsporulating, obligate thermophiles

\begin{tabular}{|c|c|c|c|c|c|c|c|c|c|}
\hline \multirow[b]{2}{*}{ Thermophile } & \multirow{2}{*}{$\begin{array}{c}\mathrm{G}+\mathrm{C} \\
(\mathrm{mol} \%)\end{array}$} & \multirow[b]{2}{*}{ Morphology } & \multirow{2}{*}{$\begin{array}{l}\text { Genera- } \\
\text { tion time }\end{array}$} & \multirow[b]{2}{*}{ Carotenoids } & \multicolumn{3}{|c|}{ Growth temp (C) } & \multirow{2}{*}{$\begin{array}{l}\text { pH op- } \\
\text { timum }\end{array}$} & \multirow{2}{*}{$\begin{array}{c}\text { Hydro- } \\
\text { carbon } \\
\text { utiliza- } \\
\text { tion }\end{array}$} \\
\hline & & & & & $\begin{array}{l}\text { Maxi- } \\
\text { mum }\end{array}$ & $\begin{array}{l}\text { Opti- } \\
\text { mum }\end{array}$ & $\begin{array}{l}\text { Mini- } \\
\text { mum }\end{array}$ & & \\
\hline $\begin{array}{l}T . \underset{\text { aquaticus, }}{\text { strains (3) }} \\
4\end{array}$ & $65.4-67.4^{a}$ & $\begin{array}{l}\text { Rods, } 5-10 \mu \mathrm{m} \\
\text { (filaments, } \\
20-200 \mu \mathrm{m} \text { ) }\end{array}$ & $50 \mathrm{~min}$ & Bright orange $^{b}$ & 79 & 70 & 40 & $7.5-7.8$ & $-r$ \\
\hline $\begin{array}{r}T . \text { thermophilus, } \\
\text { strain 4B8 (15) }\end{array}$ & $69.0^{\text {and }}$ & Rods, $3 \mu \mathrm{m}$ & $20 \mathrm{~min}$ & Yellow-orange & 85 & $65-72$ & 47 & 7.0 & $\mathrm{ND}^{e}$ \\
\hline $\begin{array}{l}T . \text { roseum ATCC } \\
27502(7)\end{array}$ & $64.3^{a}$ & $\begin{array}{l}\text { Pleomorphic } \\
\text { rods, } 3-6 \mu \mathrm{m}\end{array}$ & $5.5 \mathrm{~h}$ & Pink & 85 & $70-75$ & ND & $8.2-8.5$ & - \\
\hline$T$. fosteri PTA-1 & $68.8^{d}$ & $\begin{array}{l}\text { Pleomorphic } \\
\text { rods, } 1-1.5 \mu \mathrm{m}\end{array}$ & $4.0-4.5 \mathrm{~h}$ & Pink & 70 & 60 & 42 & $7.2-7.5$ & $+^{f}$ \\
\hline
\end{tabular}

${ }^{a}$ Determined by cesium chloride density gradient ultracentrifugation.

${ }^{b}$ Where occurring.

$c$-, No growth.

${ }^{d}$ Determined from DNA thermal denaturation temperature.

ND, Not determined.

$f+$, Growth. 


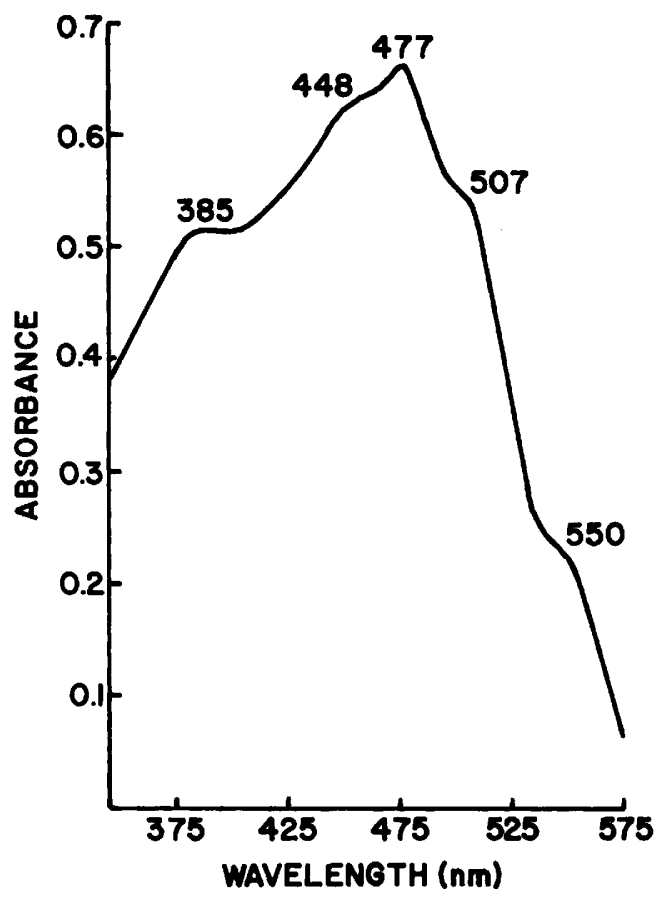

FIG. 3. Absorbance spectrum of acetone-extractable pigment(s) produced by strain PTA-1. Cultures were grown at $50 \mathrm{C}$ in L-salts basal medium with $0.2 \%$ (wt/vol) sodium acetate as the substrate.

strain PTA-1, with somewhat pleomorphic, singly occurring rods and oval-shaped cells, resembles that of $T$. roseum. The filamentous growth and "round bodies" observed in Thermus aquaticus (2) have not been seen in strain PTA-1. Strain PTA-1 produces a pink carotenoid pigment(s) similar to that described for $T$. roseum (6).

According to the results reported here, strain PTA-1 has properties that are much the same as those of Thermomicrobium roseum utilized by Jackson et al. (6) to establish the genus Thermomicrobium and to differentiate it from the genus Thermus. These properties are: (i) differences in cellular morphology, (ii) differences in type and color of the carotenoid pigment produced, and (iii) marked differences in generation time. Therefore, it is proposed that strain PTA-1 be placed in the genus Thermomicrobium. In Bergey's Manual of Determinative Bacteriology (4), this genus is placed in the section entitled "Genera of Uncertain Affiliation" under part 7, "Gram-Negative Aerobic Rods and Cocci." Moreover, strain PTA-1 is sufficiently different from $T$. roseum so as to be considered a member of a separate species (Table 2). The name proposed here for this species is Thermomicrobium fosteri sp. nov. (fos'ter.i. M. L. gen. noun fosteri of Foster; named for the late Jackson W. Foster). Because the description of this species is based on a single isolate, the species description given herein also serves as the description of the type strain.

\section{Thermomicrobium fosteri sp. nov.}

Morphology: Somewhat pleomorphic, short, singly occurring rods and small, oval-shaped rods with an average diameter of $0.5 \mu \mathrm{m}$ and an average length of $1.5 \mu \mathrm{m}$. Gram negative, nonsporulating, and nonmotile.

Cultural characteristics: Slow growth on solid media. Disperse growth usually occurs in liquid culture under static conditions. Cells contain a pink carotenoid pigment(s), especially when grown on acetate at lower temperatures.

Colony characteristics: Small, round, raised, smooth colonies.

Nutrition: No growth factors required. Growth on sodium acetate, long-chain $n$-alkanes, 1-alkenes, primary alcohols, and ketones in basal salts medium with either ammonia or nitrate as a nitrogen source. No growth occurs in nutrient broth or Trypticase soy broth.

Temperature characteristics: Grows optimally at $60 \mathrm{C}$; maximum growth temperature is $70 \mathrm{C}$; minimum growth temperature is $42 \mathrm{C}$.

Oxygen relationship: Strict aerobe.

$\mathrm{pH}$ optimum: 7.2 to 7.5 .

DNA base composition: $68.8 \mathrm{~mol} \% \mathrm{G}+\mathrm{C}$.

Type strain: PTA-1; this strain has been deposited in the American Type Culture Collection (ATCC) under the number 29033.

Source: Mud sample from littoral area (near Beaufort) on coast of North Carolina. Temperature of the overlying waters was approximately $24 \mathrm{C}$.

\section{ACKNOWLEDGMENTS}

Support for W. E. P. came from the North Carolina Agriculture Foundation.

Thanks are extended to W. R. Finnerty at the University of Georgia for electron microscopy.

\section{REPRINT REQUESTS}

Address reprint requests to: Dr. Jerome J. Perry, Department of Microbiology, North Carolina State University, Raleigh, N.C. 27607.

\section{LITERATURE CITED}

1. Allen, M. B. 1953. The thermophilic aerobic sporeforming bacteria. Bacteriol. Rev. 17:125-173.

2. Brock, T. D., and M. R. Edwards. 1970. Fine structure of Thermus aquaticus, an extreme thermophile. J. Bacteriol. 104:509-517. 
3. Brock, T. D., and H. Freeze. 1969. Thermus aquaticus gen. n. and sp. n., a nonsporulating extreme thermophile. J. Bacteriol. 98:289-297.

4. Buchanan, R. E., and N. E. Gibbons (ed.). 1974. Bergey's manual of determinative bacteriology, 8th ed., p. 285. The Williams and Wilkins Co., Baltimore.

5. Eimhjellen, K. E., and S. L. Jensen. 1964. The biosynthesis of carotenoids in Rhodopseudomonas gelatinosa. Biochem. Biophys. Acta 82:21-40.

6. Jackson, T. J., R. F. Ramaley, and W. G. Meinschein. 1973. Thermomicrobium, a new genus of extremely thermophilic bacteria. Int. J. Syst. Bacteriol. 23:2836.

7. Janssen, F. W., A. J. Lund, and L. E. Anderson. 1958. Colorimetric assay for dipicolinic acid in bacterial spores. Science 127:26-27.

8. Kellenberger, E. A., A. Ryter, and J. Sechaud. 1958. Electron microscope study of DNA-containing plasma. II. Vegetative and mature phage DNA as compared with normal bacterial nucleoids in different physiological states. J. Biophys. Biochem. Cytol. 4:671-678.

9. Kennedy, R. S., W. R. Firmerty, K. Sudarsanan, and R. A. Young. 1975. Microbial assimilation of hydrocarbons. I. The fine structure of a hydrocarbon oxidizing Acinetobacter sp. Arch. Microbiol. 102:75-83.

10. Kvasnikov, E. I., A. M. Zhuravel, and T. M. Klyushnikova. 1971. Thermophilic aerobic spore-forming, hydrocarbon-assimilating oligonitrophilic bacteria and their distinctive physiological features. Mikrobiologiya 40:509-516.

11. Leadbetter, E. R., and J. W. Foster. 1958. Studies on some methane-utilizing bacteria. Arch. Mikrobiol. 30:91-118.
12. Marmur, J. 1961. A procedure for the isolation of deoxyribonucleic acid from micro-organisms. J. Mol. Biol. 3:208-218.

13. Marmur, J., and P. Doty. 1962. Determination of the base composition of deoxyribonucleic acid from its thermal denaturation temperature. J. Mol. Biol. 5:109-118.

14. Mateles, R. I., J. N. Baruah, and S. R. Tannenbaum. 1967. Growth of a thermophilic bacterium on hydrocarbons: a new source of single-cell protein. Science 157:1322-1323.

15. Miquel, P. 1888. Monographie d'u bacille vivant audela' de $70^{\circ}$ centigrades. Ann. Micrographie 1:3-10.

16. Oshima, T., and K. Imahori. 1974. Description of Thermus thermophilus (Yoshida and Oshima) comb.nov., a nonsporulating thermophilic bacterium from a Japanese thermal spa. Int. J. Syst. Bacteriol. 24:102-112.

17. Pozomogova, I. N. 1971. Strain of Bacillus stearothermophilus growing on solid mineral medium containing liquid paraffin. Mikrobiologiya 40:866-869.

18. Pozomogova, I. N. 1971. Thermotolerant strain of $P_{\text {seu }}$ domonas aeruginosa growing on a mineral medium with liquid paraffin. Mikrobiologiya 40:1046-1049.

19. Pozomogova, I. N., S. D. Taptykova, and G. G. Sotnikov. 1972. Some physiological characteristics of thermotolerant and thermophilic microorganisms growing on media with liquid paraffin. Mikrobiologiya 41:299-305.

20. Ramaley, R. F., and J. Hixson. 1970. Isolation of a nonpigmented, thermophilic bacterium similar to Thermus aquaticus. J. Bacteriol. 103:527-528.

21. Vestal, J. R., and J. J. Perry. 1969. Divergent metabolic pathways for propane and propionate utilization by a soil isolate. J. Bacteriol. 99:216-221. 